\title{
Leczenie sanatoryjne gruźlicy płuc przed rokiem 1854
}

\section{Spa treatment of pulmonary tuberculosis before 1854}

\author{
Andrzej Kierzek ${ }^{1,2}$, Małgorzata Paprocka-Borowicz³, Jadwiga Kuciel-Lewandowska³, Wojciech Laber³, \\ Piotr Józefowski³, Jacek Kotuła ${ }^{4}$
}

${ }^{1}$ Karkonoska Państwowa Szkoła Wyższa w Jeleniej Górze, Katedra Fizjoterapii, ul. Lwówecka 18, 58-503 Jelenia Góra

${ }^{2}$ Sekcja Historyczna Polskiego Towarzystwa Otorynolaryngologów - Chirurgów Głowy i Szyi, ul. Rozbrat 5/6, 50-334 Wrocław

${ }^{3}$ Uniwersytet Medyczny im. Piastów Śląskich we Wrocławiu, Katedra Fizjoterapii, ul. Grunwaldzka 2, 50-355 Wrocław

${ }^{4}$ Specjalistyczny Gabinet Stomatologiczny, ul. Kardynała Stefana Wyszyńskiego 1, 65-525 Zielona Góra

$\bowtie$ andrzejkierzek@wp.pl

\begin{abstract}
Treatment of pulmonary tuberculosis by air and diet has been known for several thousand years. This issue was discussed by Aulus Cornelius Celsus (53 BCE-7 CE), Aretaeus of Cappadocia $\left(1-2^{\text {nd }}\right.$ century), Pliny the Elder (24-79), Galen (129-201) and others. It is assumed that the first tuberculosis sanatorium was established in Görbersdorf (Sokołowsko) in Silesia in 1854 founded by Hermann Brehmer (1821-1889), a German doctor who dealt with the treatment of respiratory diseases. But physicians had already dealt with this issue. William Buchan (1729-1805) an English physician, in his work "Treatise on domestic medicine" published in 1783, recommended patients with tuberculosis to have access to clean and fresh air, milk and horse riding. The achievements of other British doctors, especially George
\end{abstract}

Bodington (1799-1882), the author of "Essay on the treatment and cure of pulmonary consumption on principles of natural, rational and successful", are also presented. Fourteen years before Brehmer, Bodington presented the principles of treatment of pulmonary tuberculosis by air and diet in Sutton Coldfield, Warwickshire. In 1846 John Forbes (1787-1861) and Charles James Blasius Williams (1805-1889) founded the large infirmary "The Hospital for Consumption and Diseases of the Chest" in Brompton. This institution was designed exclusively for patients with tuberculosis. These were very important achievements for the spa treatment of pulmonary tuberculosis.

Keywords: history of pulmonology; history of spa treatment of tuberculosis; pulmonary tuberculosis.

\begin{abstract}
ABSTRAKT
Leczenie gruźlicy płuc powietrzem i odpowiedni dietą znane było od kilku tysięcy lat. Zagadnienie to rozpatrywane było m.in. przez Aulusa Corneliusa Celsusa (53 r. p.n.e.-7 r. n.e.), Areteusza z Kapadocji (I-II. w.), Pliniusza Starszego (24-79) i Galena. Przyjmuje się, że pierwsze sanatorium przeciwgruźlicze zostało założone w Görbersdorfie (Sokołowsko) na Śląsku w 1854 r. przez Hermanna Brehmera (1821-1889), lekarza niemieckiego, który leczył choroby dróg oddechowych. Jednak już wcześniej zajmowano się tym problemem. Angielski lekarz William Buchan (1729-1805) w wydanym w 1769 r. dziele „Domestic medicine or the family physician” zalecał na gruźlicę płuc czyste i świeże powietrze, odżywianie się mlekiem oraz przejażdżki konne.
\end{abstract}

George Bodington (1799-1882), autor „Essay on the treatment and cure of pulmonary consumption on principles natural, rational and successful", na 14 lat przed Brehmerem przedstawił zasady leczenia sanatoryjnego gruźlicy płuc powietrzem i dietą w Sutton Coldfield w hrabstwie Warwickshire. W 1846 r. John Forbes (1787-1861) i Charles James Blasius Williams (1805-1889) założyli The Hospital for Consumption and Diseases of the Chest w Brompton, duży zakład przeznaczony wyłącznie dla chorych na gruźlicę. Były to osiągnięcia niezwykle istotne dla leczenia sanatoryjnego gruźlicy płuc.

Słowa kluczowe: historia pulmonologii; historia leczenia sanatoryjnego gruźlicy; gruźlica płuc.
Pomysł leczenia gruźlicy płuc powietrzem i odpowiednią dietą liczy kilka tysięcy lat. Już Aulus Cornelius Celsus (53 r. p.n.e.-7 r. n.e.) zalecał chorym na „suchoty płucne” pobyt nad morzem. Powietrze wiejskie, szczególnie lasów iglastych, zalecali Areteusz z Kapadocji (I-II. w.) i Pliniusz Starszy (24-79). Na mleczną kurację w góry wysyłał swoich chorych Galen (129-201).

W drugiej połowie XVIII w. niezwykle modne stały się wojaże do europejskich uzdrowisk. Z powodu połączenia aspektu rekreacyjnego z charakterem kuracyjnym i towarzyskim zaczęto je traktować także jako wysublimowaną formę rozrywki [1].
W większości naukowych publikacji przyjmuje się, że pierwsze sanatorium dla chorych na gruźlicę w klimacie górskim powstało w Görbersdorfie (obecne Sokołowsko) w Sudetach Środkowych z inicjatywy Hermanna Brehmera (1826-1889), niemieckiego lekarza zajmującego się chorobami płuc [2,3].

Antoni Sabatowski, Witold S. Trybowski oraz inni historycy lecznictwa sanatoryjnego i pulmonologii sądzą, że pionierami klimatoterapii gruźlicy byli jednak lekarze z Wysp Brytyjskich. W późnych czasach nowożytnych najwcześniejszy ślad takiej terapii znaleźć można w Szkocji, gdzie w 1752 r. pewien lekarz opublikował anonimową broszurkę, w której stwierdzał, 
że najważniejszym czynnikiem w leczeniu „suchot płucnych” jest świeże powietrze i odżywianie („fresh air and diet”) [4]

Angielski lekarz William Buchan (1729-1805) w wydanym w 1769 r. dziele „Domestic medicine or the family physician” zalecał na gruźlicę płuc także czyste i świeże powietrze, odżywianie się mlekiem oraz przejażdżki konne i w powozie. W 1876 r. w Anglii powstała pierwsza lecznica nadmorska dla chorych z lżejszymi postaciami gruźlicy płuc oraz układu kostno-stawowego [5, 6, 7].

W 1791 r. w Margate w południowej Anglii założono pierwszy przeznaczony „dla zołzowatych dzieci” nadmorski szpital Royal Sea Bathing Infirmary, na ok. 50 lat przed podobnymi zakładami w innych częściach Europy. W pierwszym ćwierćwieczu XIX w. dwaj lekarze - Campbell i A. Steward również podnosili wartość takiej terapii. W 1814 r. na londyńskiej City Road otwarto Royal Hospital for Diseases of the Chest.

Antoni Kuczewski (1870-1941) - zakopiański lekarz, działacz społeczny i publicysta oraz Teodor Dunin (1854-1909) - ordynator oddziału chorób wewnętrznych Szpitala Dzieciątka Jezus w Warszawie i asystent Kliniki Terapeutycznej Cesarskiego Uniwersytetu Warszawskiego sądzili, że zarówno te, jak i późniejsze szpitale powstawały: „bynajmniej nie w świadomym celu walki z gruźlicą, ale dzięki dążeniu angielskich lekarzy do specalizacyi w leczeniu chorób" [7, 8, 9, 10].

Niezwykle ważne było pojawienie się w 1840 r. rozprawy George'a Bodingtona (1799-1882) - rycina 1- angielskiego lekarza, szczególnie zasłużonego w leczeniu chorób płuc, pt. „An essay on the treatment and cure of pulmonary consumption, on principles natural, rational, and successful". Bodington na 14 lat przed Brehmerem zaprezentował zasady leczenia sanatoryjnego gruźlicy płuc powietrzem i dietą w wybudowanym przez siebie zamkniętym zakładzie w miejscowości Sutton Coldfield w hrabstwie Warwickshire, gdzie stosowano ścisły i stały dozór lekarski nad kuracją oraz przestrzegano reżimu sanatoryjnego. Wysokie i suche położenie, piaszczysty lub żwirowy teren oraz powietrze wolne od mgieł i wilgoci były warunkiem sine qua non powodzenia kuracji. Bodington był przeciwnikiem ogólnie przyjętego sposobu leczenia tej choroby w warunkach zamkniętego pomieszczenia i wziewania rozmaitych środków. Uważał, że jedynym „nadającym się gazem” dla płuc jest czyste powietrze, którego należy używać bez obawy.
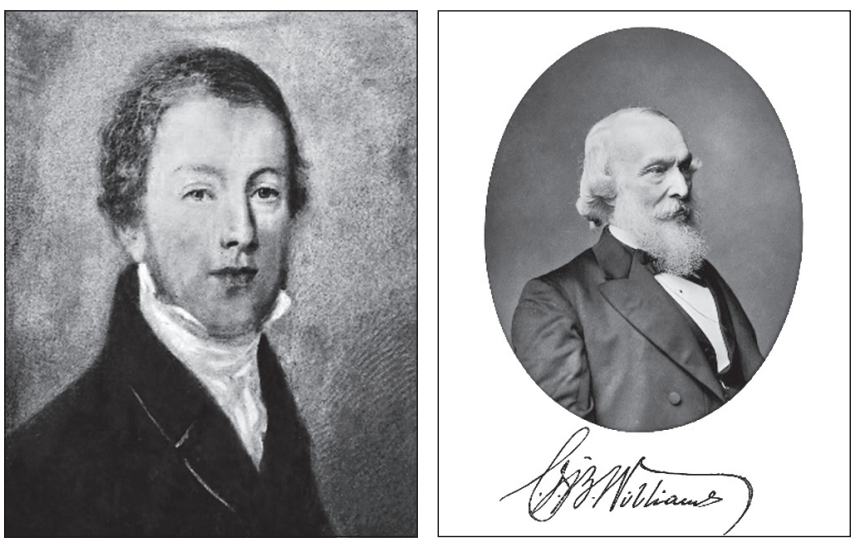

RYCINA 1. George Bodington (1799-1882) [11]
Brak powietrza stanowi stałą i najczęstszą przyczynę rozwoju choroby, a istotnym i jedynie skutecznym lekarstwem dla jej powstrzymania jest „życie i oddychanie świeżym powietrzem bez względu na wiatr i słotę". Choremu nie powinno się zabraniać ćwiczeń fizycznych na otwartym powietrzu. Obok świeżego powietrza Bodington wprowadził drugi ważny czynnik - dietę mleczną, świeże mięso i mączne pożywienie z dodatkiem wina, stosowanego jednak niezwykle oględnie. Reasumując, Bodington uważał, że „ogólny szpital w wielkim mieście jest najnieodpowiedniejszym miejscem, jakie tylko da się pomyśleć dla chorego na suchoty płucne".

Brehmera i jego metodę po początkowym okresie obojętności z zaufaniem poparli zwłaszcza chorzy cudzoziemcy, Bodington jednak takiego wsparcia otrzymać nie mógł, został wyszydzony, co spowodowało zamknięcie zakładu i przekwalifikowanie go na zakład dla umysłowo chorych.

Myśl Bodingtona nie zamarła, odradzając się w Belfaście, gdzie Henry MacCormac ogłosił dzieło pt. „On the nature, treatment and prevention of pulmonary consumption and incidentally of scrofula with the demonstration of the cause the disease". Bez wyraźnego jednak odzewu $[8,10]$.

W 1846 r. John Forbes (1787-1861) i Charles James Blasius Williams (1805-1889) - rycina 2 - założyli duży zakład „The Hospital for Consumption and Diseases of the Chest" w Brompton, na przedmieściach Londynu, przeznaczony wyłącznie dla chorych na gruźlicę.

Williams, autor m. in. „Principles of Medicine” (London 1843, 1848, 1856), w latach 1873-1875 prezydent Royal Medical and Chirurgical Society w Londynie, był dobrym lekarzem praktykiem, szczególnie w chorobach klatki piersiowej [6, 12, 13, 14, 15].

W angielskim piśmiennictwie lekarskim starano się dopatrywać związku metody Brehmera z wcześniejszymi osiągnięciami lekarzy angielskich. Kuczewski, dokonując przeglądu piśmiennictwa tak niemieckiego, jak i angielskiego, ze stanowczością twierdził, że sudeckiemu lekarzowi nie mogło być znane dzieło Bodingtona. Takie stanowisko prezentował Alfred Marcin Sokołowski w liście do Kuczewskiego, twierdząc, że Brehmer doszedł do swojej metody samodzielnie [10, 16].

Wspominając i cytując ciągle Hermanna Brehmera jako twórcę zasad klimatycznego leczenia gruźlicy metodą kuracji powietrznej i hydroterapii, nie można zapomnieć o wkładzie, jaki wnieśli lekarze brytyjscy.

\section{PIŚMIENNICTWO}

1. Kucharski A. Staropolska turystyka uzdrowiskowa w XVIII wieku. Modern Ages 2010;23:121.

2. Ortmann R. Görbersdorf. Dr Brehmer's Heilanstalten für Lungenkranke. In: Europäische Wanderbilder. Zürich; 1882.p. 64

3. Pagel J. Biographisches Lexikon hervorragender Ärzte des neunzehnten Jahrhunderts. Berlin; 1901. p. 234-5.

4. A letter from a Physician in the Highland to his friend in London, on the subject of a consumptive habit. London: C. Corbett; 1747. https://books. google.pl/books?id=deVbAAAAQAAJ (15.08.2016).

5. Ashworth S. A short history of medicine. London; 1962. p. 3

6. Trybowski WS. Polskie Towarzystwo Ftizjopneumonologiczne - powstanie i rozwój. Pneumon Pol 1986;54(7):275. 
7. Sabatowski A. Klimatoterapia oraz hydroterapia ogólna i zdrojowiskowa. Lwów; 1923. p. 7.

8. Timbell Bulstrode H. Sanatoria for consumption and certain other aspects of the tuberculosis question. London; 1908. p. 137.

9. Dunin T. Walka z gruźlicą. Warszawa; 1899. p. 7.

10. Kuczewski A. Powstanie i rozwój sanatoryjnego leczenia gruźlicy płuc. Prz Lek 1914;53(5):60.

11. Davage J. The life and times of George Bodington. London; 1981. p. 137.

12. Dictionary of National Library. London: Smith Elder \& Co; 1885-1900. p. 37.
13. Migała M. Rozwój terapii balneoklimatycznej na Górnym Śląsku w aspekcie leczenia gruźlicy (druga połowa XIX i pierwsza połowa XX wieku). Opole: Oficyna Wydawnicza Politechniki Opolskiej; 2009. p. 34

14. Sabatowski A. Leczenie klimatyczne gruźlicy. In: Janiszewski J, editor. Gruźlica i jej zwalczanie. Warszawa: Polski Związek Przeciwgruźliczy; 1927. p. 37.

15. Dobrzycki H. O konieczności oddzielnych sanatoriów dla chorych piersiowych. Medycyna 1880;18(11):161.

16. Knopf SA. Pulmonary tuberculosis, its modern prophylaxis and the treatment in special institutions and at home. Philadelphia: P. Balkiston; 1899. p. 37. 